\title{
Note on Sources and Abbreviations
}

\section{Works by Immanuel Kant}

With the exceptions of the Critique of Pure Reason (for which I follow the usual practice of citing the pagination of the 1781 (A) edition and the 1787 (B) edition) and the Critique of Judgment (for which I cite solely the Akademie pagination, reproduced in the Pluhar translation), citations from the following editions are followed by references of the form 'Ak. ... ', to Kant's Gesammelte Schriften, ed. Königlich Preussischen Akademie der Wissenschaften, 29 vols, Berlin \& Leipzig: Walter de Gruyter, 1922.

CPR Critique of Pure Reason, tr. and ed. P. Guyer \& A. Wood, Cambridge: Cambridge University Press, 1997.

CPrR Critique of Practical Reason, contained in Kant, Practical Philosophy, tr. and ed. M.J. Gregor, Cambridge: Cambridge University Press, 1996.

CJ Critique of Judgment, tr. and ed. W. Pluhar, Indianapolis, IN: Hackett, 1987.

OP Opus posthumum, tr. and ed. E. Förster and M. Rosen, Cambridge: Cambridge University Press, 1993.

C Correspondence, tr. and ed. A. Zweig, Cambridge: Cambridge University Press, 1999.

LM Lectures on Metaphysics, tr. and ed. K. Ameriks \& S. Naragon, Cambridge: Cambridge University Press, 1997.

PP Practical Philosophy, tr. and ed. M.J. Gregor, Cambridge: Cambridge University Press, 1996.

TP Theoretical Philosophy, tr. and ed. D. Walford \& R. Meerbote, Cambridge: Cambridge University Press, 1992.

\section{Works by Gilles Deleuze}

All works by Deleuze, with the exception of Difference and Repetition, are cited in translation, except where none exists. References to the 
English translation of Difference and Repetition are cited first, followed by a reference to the French edition. All other Deleuze (and Deleuze \& Guattari) references are to the extant translations.

AO Anti-Oedipus: Capitalism and Schizophrenia, vol. 1 (with Félix Guattari) [1972], trs. Robert Hurley, M. Seem \& H. R. Lane, London: Athlone Press, 1984.

ATP A Thousand Plateaus: Capitalism and Schizophrenia, vol. 2 (with Félix Guattari) [1980], tr. B. Massumi, Minneapolis: University of Minnesota Press, 1988.

B Bergsonism [1966] trs. H. Tomlinson \& B. Habberjam, New York: Zone Books, 1988.

C2 Cinema 2: The Time-Image [1985], tr. H. Tomlinson and R. Galeta (London: Athlone Press, 1989).

DI Desert Islands and Other Texts (texts 1953-74), tr. M. Taormina, New York: Semiotext(e), 2004.

DR Difference and Repetition [1968], tr. P. Patton, London: Athlone Press, 1994; Différence et répétition, Paris: PUF, 1968.

EPS Expressionism in Philosophy: Spinoza [1968], tr. M. Joughin, New York: Zone Books, 1992.

ES Empiricism and Subjectivity: An Essay on Hume's Theorv of Human Nature [1953], tr. C. V. Boundas, New York: Columbia University Press, 1991.

F The Fold: Leibniz and the Baroque (1988), tr. T. Conley, Minneapolis: University of Minnesota Press, 1993.

KCP Kant's Critical Philosophy [1963], tr. H. Tomlinson, London: Athlone Press, 1984.

LS The Logic of Sense [1969], trs. M. Lester with C. Stivale, ed. C. Boundas, London: Athlone Press, 1990.

N Negotiations: 1982-1990 (essays and interviews), tr. Martin Joughin, New York: Columbia University Press, 1995.

NP Nietzsche and Philosophy [1962], tr. Hugh Tomlinson, London: Athlone Press, 1983.

PS Proust and Signs [1964], tr. R. Howard, London: Athlone Press, 2000.

SPP Spinoza: Practical Philosophy [1981], tr. Robert Hurley, San Francisco: City Lights, 1988.

TRM Two Regimes of Madness, tr. M. Taormina, New York: Semiotext(e), 2006. 
WG Qu'est-ce que fonder? ['What Is Grounding?'], 1956 lecture course, online at webdeleuze.com.

WP What Is Philosophy? (with Félix Guattari) [1991], trs. G. Burchill and H. Tomlinson, London: Verso, 1994.

\section{Other Works}

E Spinoza, Ethics, tr. E. Curley, London: Penguin, 1996. Standard referencing is used: ' $E$ ' for Ethics, followed by Part (1-5), then definition (D), axiom (A) or proposition (P) number.

SE Sigmund Freud, Standard Edition of the Complete Psychological Works of Sigmund Freud, 24 vols, ed. James Strachey, London: Hogarth Press, 1953-74. 